\title{
The Information Content of Stock Market Flows: Evidence from Thailand
}

\author{
Chollaya Chotivetthamrong $^{1} \&$ Aekkachai Nittayagasetwat ${ }^{1}$ \\ ${ }^{1}$ School of Business Administration, National Institute of Development Administration, Bangkok, Thailand \\ Correspondence: Chollaya Chotivetthamrong, School of Business Administration, National Institute of \\ Development Administration, Bangkok, Thailand. E-mail: ja_san@live.com
}

Received: April 28, 2014

Accepted: May 12, 2014

Online Published: June 25, 2014

doi:10.5539/ibr.v7n7p106

URL: http://dx.doi.org/10.5539/ibr.v7n7p106

\begin{abstract}
This paper studies the impact of Thai stock market (SET) by examining the return-volume relation and the weekly volatility-volume relation, started 2003-2014. The results show that there is a positive relation in return-volume relation; although, there is a negative relation of volatility-volume. In addition, we differentiate the impact of fund inflow and outflow for each individual groups, including foreign, local and institution investors for finding the relations between fund flow and market return, between fund flow and market volatility. The analysis shows that only foreign investor impacts to stock market in both of trading-return relation and trading-volatility relation. There is a positive relation with market return, but has a negative relation with market volatility. However, it depends on direction of fund flow. Fund inflow has positive relation in market return while outflow has negatively. On the other hand, in part of trading-market volatility, the larger of cash outflow, the more volatility is the market.
\end{abstract}

Keywords: foreign, fund flows, information content, institution, investor, local, relation, return, trading, volatility, volume

\section{Introduction}

The impact of stock market volatility on stock price has received considerable and attention in recent years since the stock crash of October 1987 (Chang \& Wang, 2002). The stock market crash on October 19, 1987 made all changes in the investors' behavior. Refer to Schwert (1990), he mentioned that all the major networks flashed reports on the market decline. The investors just wondered whether stock prices have not become too volatile, and studied the effects of program trading, index arbitrage and other modern investment techniques on the volatility of stock prices. As of this crisis, the investors, brokers, and dealers have all expressed concern over the level of stock market volatility, especially in this recent years, which the prices move a lot more.

Market volatility is derived from the variation of stock price over time or time-varying effect. Volatility has changed over time. There are several empirical researches that study about market volatility with return data the period. Schwert (1989) observed monthly data with stock volatility from 1857 to 1987.

$\mathrm{Li}$ and $\mathrm{Wu}$ (2006) examined the daily information flow with return volatility from January 4, 1988 to August 31, 2001. Their example period was selected to avoid the 1987 stock market crash. Lockwood and Linn (1990) examined the market return with volatility during 1964-1989 and they concluded that the observed volatility during intraday is higher than overnight period. As a result, most of the researchers concluded that market volatility effect on return prices. Hauger, Talmor and Torous (1991) observed a strong variation of volatility during 1897 through 1988 by using daily return data.

Moreover, there are a number of empirical studies on the volatility-volume relationship. Started by Clark (1973), He pioneered the interesting distribution to explain this relation with hypothesis test. This approach pointed the relationship between the price changes and volume on the underlying information.

According to $\mathrm{Li}$ and $\mathrm{Wu}$ (2006), they explained another interesting topic about the relationship between return volatility and training volume. They used MDH model, generalized by Clark (1973) to test the effects of informed and liquidity trading volumes on return volatility and information flow. Their results showed the positive relationship between volatility and volume for the informed component of training.

As a result, this paper will examine those interesting topic in financial research as the impact of stock market 
volatility on stock price and the relationship between volatility and volume. In addition, Thailand Stock market has separated investors as foreign, local, and institution. As a result, this paper will find the main contributor investor that impact the stock return and volatility.

This paper is organized as follows. Section 1 is an introduction. Section 2 reviews the literature about market volatility and return data. Section 3 and 4 presents data selection, and empirical methodology, respectively. Section 5 presents empirical results. The paper concludes with Section 6.

\section{Review of Literature}

Volatility became more attention in stock market since 1987 or stock crash in US. Most of the investors, brokers and dealers studied that crisis and understood that stock prices became too volatile. Volatility is measured from variation of stock price over time.

There are several researches to understand and observe the market volatility. Edwards (1988), he observed and found that more volatility during 1920's due to the uncertainty and financial risks the same as Schwert (1990). He analyzed the behavior of stock return volatility using daily data from 1885 through 1988. During the crisis (the Octorber 1987), stock market crash was unusual in many ways. October 19 was the largest percentage change in market value. Stock volatility jumped dramatically during and after the crash.

French, et al. (1987) examined the relation between stock return and stock market volatility. They found that there was a positive related to the predicable volatility of stock return. Guo and Savickas (2006) agreed with French, et al. (1987)'s result. They found that the volatility exhibited stock predictive power for stock market return. They concluded that the investors should understand the volatility for predict the stock return correctly.

Warther $(1995,1998)$ supported the previous studies. He found a very strong relation between unexpected flow and returns at monthly frequency. Warter (1995) found a very high correlation between month flow and return.

However, there are some empirical studies that argued with previous studies' result. Reilly (1979) found that institutional trading reduced stock price volatility rather than promoting it.

Campbell (1992) found the same result as Reilly (1979). He analyzed daily stock returns over the period 1926-1988 and found an interesting result of the relationship between volatility and returns that the volatility feedback normally had little effect on return, but it could be important during periods of high volatility. Thus, this study will examine the relation between stock return and volatility in Thai stock market to find the impact of volatility in emerging market.

Moreover, Brooks (1998) found an interesting issue. He studied a number of statistical models for predicting the daily stock return and volatility. He found that there is another relation that is the relation between stock volatility and volume. There was a stronger from volatility to volume than the other way around.

Fung and Patterson (1999) examined the dynamic interactions among return volatilities, volume and market depth for five currency futures markets. They found that return volatility got a strong effect from trading volume and market depth.

Chan and Fung (1998) examined the relation between volatility and volume as Brooks (1998)'s testing. They examined the roles of the number of trades, size of trades, and order imbalance in explaining the volatility-volume relation for a sample of NYSE and Nasdaq stocks. They found that the order in large trade size categories affects the return more than in smaller size categories.

Wantanabe (2001) examined the relation between price volatility and trading volume for the Nikkei 225 stock index futures traded on the Osaka Securities Exchange (SOE). They also got the same result as previous studies that is a significant positive relation between volatility and volume.

In addition, there are several studies that presented different method to calculate stock volatility. Manaster and Koehler (1982) studied how to calculate European stock option. They suggested that there are many authors tried to figure it out to find the best formula for volatility measurement. However, they concluded that Black Scholes's model is one of the best formulas, because it included the maturity of time.

However, Engle and NG (1993) argued for that idea. They observed and studied market volatility for Japanese stock market. They found that due to different market flow and information limitation. Black Scholes's model cannot explain all. They calculated the stock volatility by using stock price over the period and applying in EGARCH model for analysis.

Moreover, in order to examine the market volatility, Chang and Wang (2002) suggested to estimate the volatility based on the parametric econometric models such as generalized autoregressive conditional hetero-skedasticity 
(GARCH) or stochastic volatility models, or the implied volatility based on option prices and a pricing model such as Black-Scholes, or the historical volatility cased on ex post squared or absolute returns. They compared the calculated volatility with volatility index from the market. In their study, they used three methods for analysis that are Andersen, et el (2001) developed for a daily volatility estimator by summing intraday squared returns, Parkinson (1980) developed for the extreme value, and volatility index of Chicago Board Options Exchange (CBOE). However, they found that all calculated volatilities go into the same result.

As a result, the previous researches are shown that each market may match in different volatility measurement method. The researcher should use the one that match with market index. This paper will use the different volatility methods that are the standard method and Parkinson (1980) method to show the market volatility with volatility relationship.

Additionally, according to globalization, all stock markets opened to all foreigners to invest in their market. According to Takada (2014), he reported that China has relaxed rules to allow more foreign participation in its main stock market, in the latest step towards liberalizing the financial system in the world's second-largest economy.

As a result, after open market to the foreigners, there are several interesting situation occurred. There are a lot of studies to analyze how influence of investor type into stock return, especially in foreign investor. According to Hsu (2013), foreign investors have played an increasingly important role in the stock markets of emerging host countries. He empirically tested whether the foreign investors influence on the stock outperforms. The findings showed that the foreign investor favored group outperformed.

Referring to Choe et al. (1999), they examined the impact of foreign investors on stock returns in Korea from November 30, 1996 to the end of 1997 using order and trade data to analyze the relationship between foreign investors and stock return. They found there is a strong positive relationship before the period of Korea's economic crisis.

The research of Richards (2005) agreed with those previous studies. He analyzes a dataset of daily trading of all foreign investors in six Asian emerging equity markets. He found that the foreigners' flows into several markets showed positive feedback in the domestic returns. The results suggested that foreign investors had a larger impact on emerging markets.

Jaffe and Westerfield (1985) supported that result. They examined the daily stock market returns for foreign countries. They showed that there is a seasonal pattern in stock market when there is a foreigner investment into the market. However, due to different time zone, the effects showed in different day in different country, which they called "week-end effect" in each country. For example, the lowest mean returns for the Japanese and Australian stock markets occur on Tuesday. Thus, it can imply in this case that the foreign investor had a strong relationship in the overall stock market.

However, not only volatility that impact to investment decision but also market flow some investors consider on market flow as one of the factors for investment. According to Haugen and Baker (1991), they observed in investment methods and explained that investors included a number of factors for decision making not only market volatility in part of local and global but also market flow.

As a result, there are two interesting factors that impact of fund flows in stock return and market volatility, and the impact of investor groups to return and market volatility. This paper will examine the relationship between those factors in the emerging market as Thailand.

\section{Data Selection}

Most of previous studies were interested in US and/or European market for analysis; however, this paper will focus on the emerging market as Thai stock market. Moreover, this paper will separate the analysis into two parts that are the overall stock market relation and separate those relations into each investor group.

Our data come from the daily stock price in the Stock Exchange of Thailand market or SET, started on January 2, 2003- February 28, 2014 or 2,748 observations. For investor group analysis, we collect data from SET daily data by separate the price into three investors that are foreign, local, institution investors. However, due to data limitation, in part of volatility, we will examine as weekly basis in the same period of time for both overall and investor group analysis.

\section{Methodology}

This paper separates the methodologies into two main parts that are the volatility analysis and the influence of foreign investors. Moreover, the paper will show the relationship between those independent variables and stock 
return.

In order to examine the volatility for the Stock Exchange of Thailand, this paper examines as two well-known methods, and compares the result to ensure that the data should be reasonable. According to Chang and Wang (2002), they suggested that to prevent the inferences from being sensitive to particular volatility estimators used, they used two other estimators to check the robustness of the result.

The first method is the simplest way for volatility estimator to calculate daily periodic return and find the standard deviation. This paper calls this volatility estimator as "Periodic volatility", which is defined as:

$$
\sigma \mathrm{a}=\frac{\sigma s d}{\sqrt{T}}
$$

where

$\boldsymbol{\sigma}$ a denotes the weekly volatility

$\sigma$ sd denote the daily logarithmic returns of a stock, which $\mathrm{P}$ defines as daily price at day $\mathrm{t}$

$\sigma$ sd $=\ln \sigma(\mathrm{Pt} /(\mathrm{Pt}-1))$

$\mathrm{T}$ denotes the time period of return

Another method was developed by Parkinson (1980) to estimate the volatility of returns for a random walks using the high and low in any particular period. Prices are observed on a fixed time interval as $n=10,20,30,60$, 90, 120, 150, 180 days, which is defined as:

$$
\sigma \mathrm{p}=\frac{\sqrt{\sum_{t=1}^{n} \frac{1}{4 \ln 2}\left(\ln \frac{P_{H}}{P_{L}}\right)^{2}}}{n}
$$

where

PH and PL denote respectively the highest and lowest index prices on day $\mathrm{t}$ in SET. This paper calls this volatility as "Extremely volatility".

To prevent the robustness, Chang and Wang (2002) suggested examining the correlation between the volatility in each method. This paper will find the correlation between those two methods, frequency volatility and extremely volatility, by using data analysis in Excel.

In addition, this paper will focus on the relationship that impact the stock return. This paper will separate into two main sections that are the volatility-volume relation and/or the return-volume relation. We use the differentiated for each factor. In addition, this paper will differentiated into each investor to find the group that impact to the stock return.

\section{Empirical Results}

\subsection{Volatility Results}

In order to examine the volatility, the first method is using the standard deviation of return SET during 2003-February 2014 or 2,748 observations, shown in Figure 1.

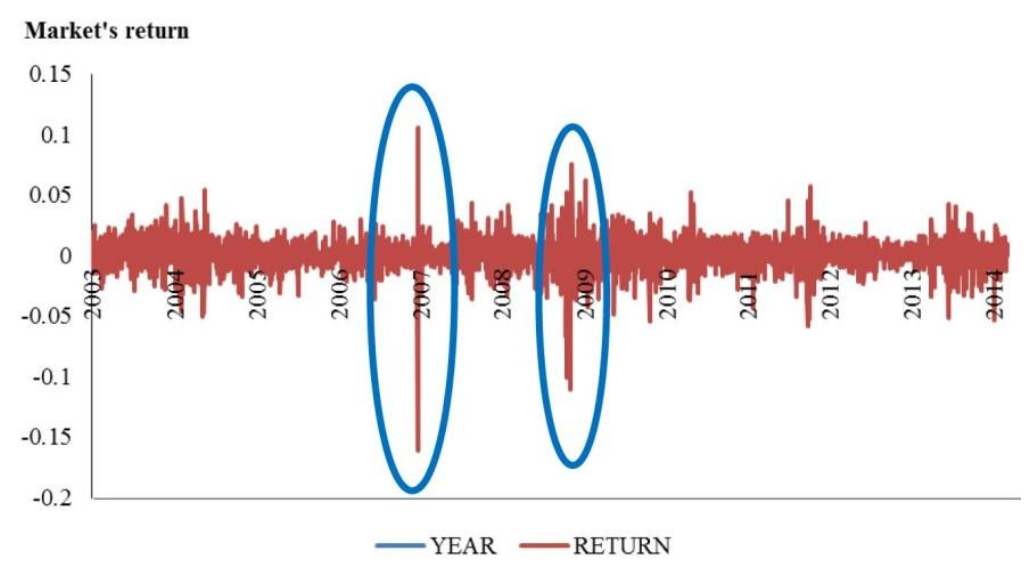

Figure 1. Time series of daily return of SET 
Figure 1 shows the time series of daily return of SET, covering the period from January 2, 2003 through February 28, 2014, for a total of 2,748 observations. The return obviously fluctuates, in 2007, the highest return is around 0.12 to the lowest return is approximately -0.17 vs average 0.001 , or the started period of Sub-prime crisis, and in 2009 or during global economic crisis, started in Q3 2008 to 2009.

Dooley and Hutchison's (2009) studied the stock return in emerging market during Sub-prime crisis, started in 2007 to summer in 2008. They explained that emerging markets responded very strongly to the deteriorating situation in the U.S. financial system and real economy. Their regression "event study," focusing on 15 types of news, indicated that the real economic news emanating from the US had statistically and economically large impacts on 14 emerging markets and several news events uniformly moved markets.

In order of volatility, the paper analyzes the volatility as weekly basis. The first method in this paper is using the simplest methodology that is using the standard deviation of daily return. This paper calls the result of this volatility as "Frequency volatility". Another method is Parkinson's model. Parkinson (1980) developed the model to find volatility by calculating the extreme value as highest and lowest price in the fix period of time. This paper calls this volatility as "Extremely volatility". The result of these methods is shown in Figure 2.

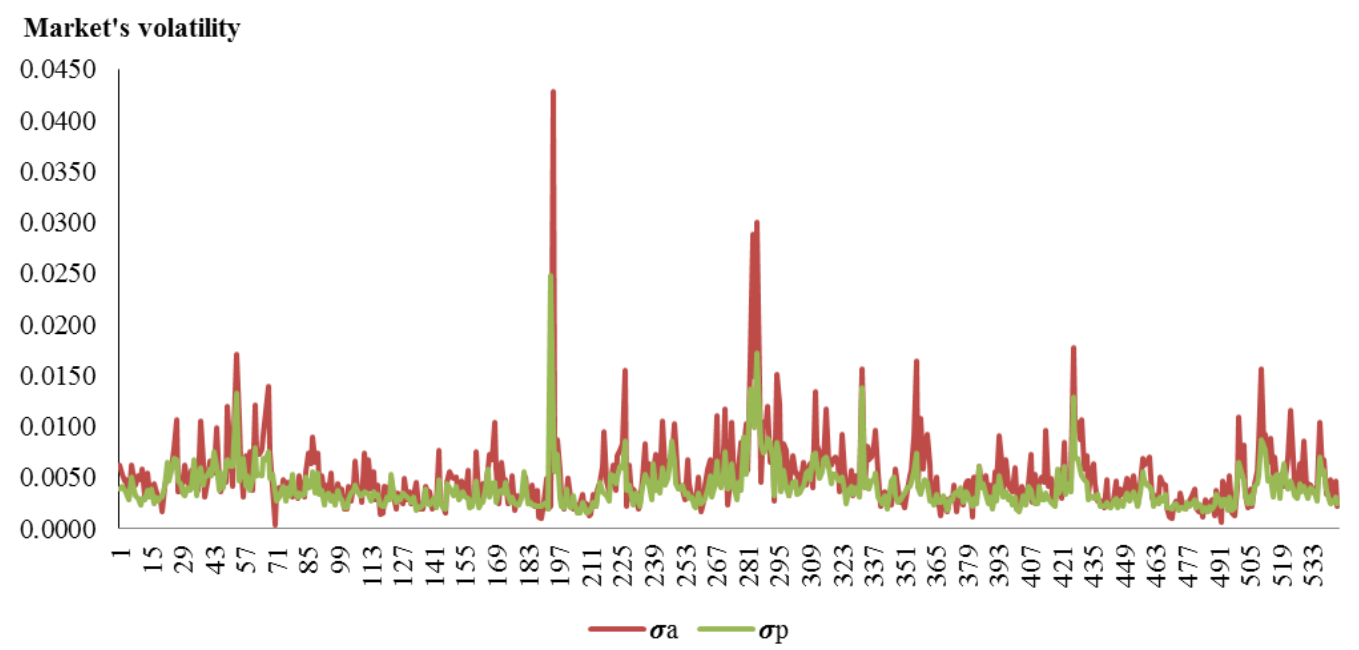

Figure 2. Time-series of frequency and extremely volatilities

Figure 2 presents the time series of volatilities, comparing between frequency and extremely volatilities, since 2003-February, 28, 2014, for the total of 2,748 observations. The frequency volatility represents as $\sigma_{\mathrm{a}}$, and the extremely volatility represents as $\boldsymbol{\sigma}_{\mathrm{p}}$. According to figure 2 , it is illustrated that both of them have the same trend of time series of voliality; however, the frequency volatility is higher value than extremely volatility.

Moreover, refer to to Chang and Wang (2002), they suggested that to prevent the robustness of result, we should examine the correlation between those volatilities. From their study, they used 3 volatility methods that were high-frequency volatility, calculated from the daily data, high-low volatility that way from Parkinson method and volatility index from the Chicago Board Options Exchange (CBOE), for their testing. Their results found that the high-frequency volatility got the highest number with highly correlated with other methods. Thus, they used the high-frequency volatility as the main volatility for calculation.

According to Chang and Wang (2002), this paper examines the correlation between our volatilities to prevent the robustness and to find the representative volatility for analysis if investor would like to find the volatility in Thai stock market. To test the correlation, this paper uses data analysis in MS Excel, which is shown in Table 1.

Table 1. Summary statistics for volatility correlation (Time period: January 2, 2003- February 28, 2014)

\begin{tabular}{lcc}
\hline & $\sigma \mathrm{a}$ & $\sigma \mathrm{p}$ \\
\hline$\sigma \mathrm{a}$ & 1.0000 & \\
$\sigma \mathrm{p}$ & $0.7060^{*}$ & 1.0000 \\
\hline
\end{tabular}

*Significant at 0.05 level, two-tailed test. 
Table 1 shows that there is a highly correlation between those two volatilities. Even using the different method to calculate volatility, it will show the same trend for analysis for Thai stock market. For brevity, we will use the frequency volatility as a representative of volatility. However, there is not only volatility that impacts the stock return but also the volatility-volume or return-volume relation. The next testing will focus on the relation, including the relation in each investor to find the main impact investor.

\subsection{Relation Results}

We will separate into two main parts that are the relation of overall stock market testing and the relation in each group of investor, respectively. Firstly, we will test the overall stock market for both relations by using differentiate of return-volume and volatility-volume as the following model:

$$
\begin{aligned}
& \operatorname{Ln}(r t)=a+b \operatorname{Ln}(V t)+\varepsilon t \\
& \operatorname{Ln}(\sigma 2)=a+b \operatorname{Ln}(V t)+\varepsilon t
\end{aligned}
$$

where

rt refer to stock return at time or $\mathrm{Ln}(\mathrm{rt})=\mathrm{Ln}(\mathrm{St} /(\mathrm{St}-1))$;

$\mathrm{Vt}$ refer to volume at $\mathrm{t}$ time;

$\boldsymbol{\sigma} \mathrm{t} 2$ refer to stock volatility or frequency volatility at $\mathrm{t}$ time;

The result of the return-volume relation is shown in table 2.

\begin{tabular}{|c|c|c|c|c|c|c|}
\hline \multicolumn{7}{|c|}{ Regression Statistics } \\
\hline \multicolumn{2}{|c|}{ Multiple R } & \multicolumn{5}{|l|}{0.0178} \\
\hline \multicolumn{2}{|l|}{ R Square } & \multicolumn{5}{|l|}{0.0003} \\
\hline \multicolumn{2}{|c|}{ Adjusted R Square } & \multicolumn{5}{|l|}{0.0000} \\
\hline \multicolumn{2}{|c|}{ Standard Error } & \multicolumn{5}{|l|}{0.0140} \\
\hline \multicolumn{2}{|c|}{ Observations } & \multicolumn{5}{|l|}{2,730} \\
\hline & Coefficients & $\begin{array}{c}\text { Standard } \\
\text { Error }\end{array}$ & t Stat & P-value & Lower $95 \%$ & Upper $95 \%$ \\
\hline Intercept & -0.0071 & 0.0081 & -0.8707 & 0.3840 & -0.0230 & 0.0088 \\
\hline $\operatorname{Ln}(v)$ & 0.0003 & 0.0004 & 0.9311 & 0.0035 & -0.0004 & 0.0011 \\
\hline
\end{tabular}

Table 2. Regression of return-volume relation

Table 2 indicates that there is a positive correlation between return-volume, which is the same result as Chan et. el (2001). They tested the dynamic relation between returns, volume, and volatility of stock indexes from 1973 to 2000. The results showed a positive correlation between trading volume and return. Another testing is the relation between volatility-volume, is shown in table 3 .

\begin{tabular}{|c|c|c|c|c|c|c|}
\hline \multicolumn{7}{|c|}{ Regression Statistics } \\
\hline \multicolumn{2}{|c|}{ Multiple R } & \multicolumn{5}{|l|}{0.0357} \\
\hline \multicolumn{2}{|l|}{ R Square } & \multicolumn{5}{|l|}{0.0013} \\
\hline \multicolumn{2}{|c|}{ Adjusted R Square } & \multicolumn{5}{|l|}{-0.0006} \\
\hline \multicolumn{2}{|c|}{ Standard Error } & \multicolumn{5}{|l|}{1.1096} \\
\hline \multicolumn{2}{|c|}{ Observations } & \multicolumn{5}{|l|}{544} \\
\hline & Coefficients & Standard Error & t Stat & P-value & Lower $95 \%$ & Upper $95 \%$ \\
\hline Intercept & -9.4892 & 1.6335 & -5.8092 & 0.0000 & -12.6979 & -6.2805 \\
\hline $\operatorname{Ln}(v)$ & -0.0584 & 0.0702 & -0.8317 & 0.0041 & -0.1962 & -0.1962 \\
\hline
\end{tabular}

Table 3. Regression of volatility-volume relation 
Table 3 illustrates that there is a negative relation between volatility-volume. According to $\mathrm{Li}$ and $\mathrm{Wu}(2006)$, they agreed with the result that volatility is negatively related to trading volume. As a result for Thai stock market, period of 2003- February 28, 2014, there is a positive relation between return and volume, but a negative relation between volatility and volume. Thus, when the return increases or price changes, volume increases. However, when the volume increases, the volatility will be decreased.

Moreover, this paper will consider on the group of investor that impact to the stock market, calculating by the relation of return-buy/sell price and volatility-buy/sell price. As above present, there are three main groups of investors that are foreigner, local and institution. For group analysis, this paper differentiates the impact of fund flows, including inflow and outflow, respectively, presenting the following models for analysis:

$$
\begin{aligned}
\operatorname{Ln}(r t) & =a+b \operatorname{Ln}(\mathrm{Gt})+\varepsilon t \\
\operatorname{Ln}(\text { rt }) & =a^{\prime}+b^{\prime} \operatorname{Ln}(\mathrm{Bt} / \mathrm{St})+\varepsilon^{\prime} t \\
\operatorname{Ln}(\text { rit } 2) & =a^{\prime}+b^{\prime} \operatorname{Ln}(\text { Bit } / \text { Sit })+\varepsilon^{\prime} t \\
\operatorname{Ln}(\text { rot } 2) & =a^{\prime}+b^{\prime} \operatorname{Ln}(\text { Bot } / \text { Sot })+\varepsilon^{\prime} t
\end{aligned}
$$

where

rt refer to stock return at t time or $\mathrm{Ln}(\mathrm{rt})=\mathrm{Ln}(\mathrm{St} /(\mathrm{St}-1))$;

rit refer to stock return at $\mathrm{t}$ time or $\mathrm{Ln}(\mathrm{rt})=\mathrm{Ln}(\mathrm{St} /(\mathrm{St}-1))$ in cash inflow $(\mathrm{Bt}>\mathrm{St})$;

rot refer to stock return at $\mathrm{t}$ time or $\mathrm{Ln}(\mathrm{rt})=\mathrm{Ln}(\mathrm{St} /(\mathrm{St}-1))$ in cash outflow $(\mathrm{Bt}<\mathrm{St})$;

Bt refer to buy price for overall market at t time;

Bit refer to buy price in cash inflow $(\mathrm{Bt}>\mathrm{St})$ at $\mathrm{t}$ time;

Bot refer to buy price in cash outflow $(\mathrm{Bt}<\mathrm{St})$ at $\mathrm{t}$ time;

St refer to sell price for overall market at t time;

Sit refer to sell price in cash inflow $(\mathrm{Bt}>\mathrm{St})$ at $\mathrm{t}$ time;

Bot refer to sell price in cash outflow $(\mathrm{Bt}<\mathrm{St})$ at $\mathrm{t}$ time;

For analysis in each group, we separates as three groups that are foreigner, local and institution as group 1, group

\begin{tabular}{|c|c|c|c|c|c|c|}
\hline \multicolumn{7}{|c|}{ Regression Statistics } \\
\hline \multicolumn{2}{|c|}{ Multiple R } & \multicolumn{5}{|l|}{0.2195} \\
\hline \multicolumn{2}{|l|}{ R Square } & \multicolumn{5}{|l|}{0.0482} \\
\hline \multicolumn{2}{|c|}{ Adjusted R Square } & \multicolumn{5}{|l|}{0.0478} \\
\hline \multicolumn{2}{|c|}{ Standard Error } & \multicolumn{5}{|l|}{0.0137} \\
\hline \multicolumn{2}{|c|}{ Observations } & \multicolumn{5}{|l|}{2,730} \\
\hline & Coefficients & Standard Error & t Stat & P-value & Lower 95\% & Upper $95 \%$ \\
\hline Intercept & -0.0006 & 0.0003 & 2.1836 & 0.0291 & 0.0001 & 0.0011 \\
\hline $\operatorname{Ln}(\mathrm{v})$ & $0.0101 *$ & 0.0009 & 11.7527 & 0.0000 & 0.0084 & 0.0118 \\
\hline
\end{tabular}
2 , group 3, respectively. The results for foreign investor as the following tables, Table 4-6.

Table 4. Regression of return-buy/sell price for foreigner

Time period: January 2, 2003 - February 28, 2014 (2,730 observations)

Table 4 presents that there is a positive relation between return and buy-sell price, agrees with several empirical research (i.e., Choe et al., (1999), Richards (2005)). Choe et al., (1999) examined the impact of foreign investors on stock returns in Korea from November 30, 1996 to the end of 1997 using order and trade data. They found strong evidence of positive feedback trading and herding by foreign investors.

Richards (2005) analyzed daily trading of all foreign investors in six Asian emerging equity markets. He found that foreigners' flows into several markets show positive feedback trading with respect to global, as well as 
domestic, equity returns. The nature of this trading suggested that it is due to behavioral factors or foreigners extracting information from recent returns, rather than portfolio rebalancing effects. In addition, table 5 and table 6 analyze the relation between return-buy/sell by separate into cash flow.

Table 5. Regression of return-buy/sell price for foreigner in cash inflow

Time period: January 2, 2003 - February 28, 2014 (1,386 observations)

\begin{tabular}{|c|c|c|c|c|c|c|}
\hline \multicolumn{7}{|c|}{ Regression Statistics } \\
\hline \multicolumn{2}{|c|}{ Multiple R } & \multicolumn{5}{|l|}{0.0766} \\
\hline \multicolumn{2}{|l|}{ R Square } & \multicolumn{5}{|l|}{0.0059} \\
\hline \multicolumn{2}{|c|}{ Adjusted R Square } & \multicolumn{5}{|l|}{0.0051} \\
\hline \multicolumn{2}{|c|}{ Standard Error } & \multicolumn{5}{|l|}{0.0198} \\
\hline \multicolumn{2}{|c|}{ Observations } & \multicolumn{5}{|l|}{1,386} \\
\hline & Coefficients & Standard Error & t Stat & P-value & Lower $95 \%$ & Upper $95 \%$ \\
\hline Intercept & -0.0063 & 0.0026 & -2.4335 & 0.0151 & -0.0113 & -0.0012 \\
\hline $\operatorname{Ln}(\mathrm{v})$ & $0.0057 *$ & 0.0020 & 2.8582 & 0.0043 & 0.0018 & 0.0096 \\
\hline
\end{tabular}

Table 6. Regression of return-buy/sell price for foreigner in cash outflow

Time period: January 2, 2003 - February 28, 2014 (1,343 observations)

\begin{tabular}{|c|c|c|c|c|c|c|}
\hline \multicolumn{7}{|c|}{ Regression Statistics } \\
\hline \multicolumn{2}{|c|}{ Multiple R } & \multicolumn{5}{|l|}{0.2304} \\
\hline \multicolumn{2}{|c|}{ R Square } & \multicolumn{5}{|l|}{0.0531} \\
\hline \multicolumn{2}{|c|}{ Adjusted R Square } & \multicolumn{5}{|l|}{0.0524} \\
\hline \multicolumn{2}{|c|}{ Standard Error } & \multicolumn{5}{|l|}{0.0209} \\
\hline \multicolumn{2}{|c|}{ Observations } & \multicolumn{5}{|l|}{1,343} \\
\hline & Coefficients & Standard Error & t Stat & P-value & Lower $95 \%$ & Upper $95 \%$ \\
\hline Intercept & -0.0260 & 0.0032 & -8.2156 & 0.0000 & -0.0323 & -0.0198 \\
\hline $\operatorname{Ln}(v)$ & $-0.0338^{*}$ & 0.0039 & 8.6691 & 0.0000 & 0.0262 & 0.0415 \\
\hline
\end{tabular}

Table 5 and table 6 explain more about this relation that the relation, and show that the relation depends on the direction of flow. Fund inflow is positive related to market return; in contrast with fund outflow.

The results for local and institution investors are shown in the following tables:

Table 7. Regression of return-buy/sell price for local investor

Time period: January 2, 2003 - February 28, 2014 (2,730 observations)

\begin{tabular}{|c|c|c|c|c|c|c|}
\hline \multicolumn{7}{|c|}{ Regression Statistics } \\
\hline \multicolumn{2}{|c|}{ Multiple R } & \multicolumn{5}{|l|}{0.5011} \\
\hline \multicolumn{2}{|l|}{ R Square } & \multicolumn{5}{|l|}{0.2511} \\
\hline \multicolumn{2}{|c|}{ Adjusted R Square } & \multicolumn{5}{|l|}{0.2508} \\
\hline \multicolumn{2}{|c|}{ Standard Error } & \multicolumn{5}{|l|}{0.0121} \\
\hline \multicolumn{2}{|c|}{ Observations } & \multicolumn{5}{|l|}{2,730} \\
\hline & Coefficients & Standard Error & t Stat & P-value & Lower $95 \%$ & Upper $95 \%$ \\
\hline Intercept & 0.0453 & 0.0015 & 30.2030 & 0.0000 & 0.0424 & 0.0483 \\
\hline $\operatorname{Ln}(v)$ & -0.0440 & 0.0015 & -30.2422 & 1.6264 & -0.4681 & -0.4111 \\
\hline
\end{tabular}


Table 8. Regression of return-buy/sell price for institution investor

Time period: January 2, 2003 - February 28, 2014 (2,730 observations)

\begin{tabular}{|c|c|c|c|c|c|c|}
\hline \multicolumn{7}{|c|}{ Regression Statistics } \\
\hline \multicolumn{2}{|c|}{ Multiple R } & \multicolumn{5}{|l|}{0.2243} \\
\hline \multicolumn{2}{|l|}{ R Square } & \multicolumn{5}{|l|}{0.0503} \\
\hline \multicolumn{2}{|c|}{ Adjusted R Square } & \multicolumn{5}{|l|}{0.0500} \\
\hline \multicolumn{2}{|c|}{ Standard Error } & \multicolumn{5}{|l|}{0.0136} \\
\hline \multicolumn{2}{|c|}{ Observations } & \multicolumn{5}{|l|}{2,730} \\
\hline & Coefficients & Standard Error & t Stat & P-value & Lower 95\% & Upper $95 \%$ \\
\hline Intercept & 0.0004 & 0.0003 & 1.6811 & 0.0929 & -0.0001 & 0.0010 \\
\hline $\operatorname{Ln}(v)$ & -0.0080 & 0.0007 & -12.0205 & 1.8067 & -0.9339 & -0.6719 \\
\hline
\end{tabular}

Table 7 and table 8 presents the result of return-buy/sell price for local and institution investors that there is no impact to return for both investors. An interesting finding for this analysis is that there is only correlation between investor group and market return from foreign investor as positive correlated, depending on the direction of flow: fund inflow is positive, but outflow is negative.

Another analysis is the relation between volatility and buy-sell price, this paper uses this following model for analysis:

$$
\begin{gathered}
\operatorname{Ln}(\sigma t 2)=a+b \operatorname{Ln}(G t)+\varepsilon t \\
\operatorname{Ln}(\sigma t 2)=a^{\prime}+b^{\prime} \operatorname{Ln}(B t / S t)+\varepsilon^{\prime} t \\
\operatorname{Ln}(\sigma i t 2)=a^{\prime}+b^{\prime} \operatorname{Ln}(\text { Bit } / \text { Sit })+\varepsilon^{\prime} t \\
\operatorname{Ln}(\boldsymbol{\sigma o t} 2)=a^{\prime}+b^{\prime} \operatorname{Ln}(\text { Bot } / \text { Sot })+\varepsilon^{\prime} t
\end{gathered}
$$

where

$\sigma \mathrm{t} 2$ refer to stock volatility or frequency volatility at $\mathrm{t}$ time;

$\boldsymbol{\sigma}$ it2 refer to stock volatility or frequency volatility in cash inflow $(\mathrm{Bt}>\mathrm{St})$ at t time;

$\sigma$ ot 2 refer to stock volatility or frequency volatility in cash outflow $(\mathrm{Bt}<\mathrm{St})$ at $\mathrm{t}$ time;

Bt refer to buy price for overall market at t time;

Bit refer to buy price in cash inflow $(\mathrm{Bt}>\mathrm{St})$ at $\mathrm{t}$ time;

Bot refer to buy price in cash outflow $(\mathrm{Bt}<\mathrm{St})$ at $\mathrm{t}$ time;

St refer to sell price for overall market at $t$ time;

Sit refer to sell price in cash inflow $(\mathrm{Bt}>\mathrm{St})$ at $\mathrm{t}$ time;

Bot refer to sell price in cash outflow $(\mathrm{Bt}<\mathrm{St})$ at $\mathrm{t}$ time;

For analysis in each group, we separates as three groups that are foreigner, local and institution as group 1, group

\begin{tabular}{|c|c|c|c|c|c|c|}
\hline \multicolumn{7}{|c|}{ Regression Statistics } \\
\hline \multicolumn{2}{|c|}{ Multiple R } & \multicolumn{5}{|l|}{0.1602} \\
\hline \multicolumn{2}{|l|}{ R Square } & \multicolumn{5}{|l|}{0.0257} \\
\hline \multicolumn{2}{|c|}{ Adjusted R Square } & \multicolumn{5}{|l|}{0.0239} \\
\hline \multicolumn{2}{|c|}{ Standard Error } & \multicolumn{5}{|l|}{1.0960} \\
\hline \multicolumn{2}{|c|}{ Observations } & \multicolumn{5}{|l|}{544} \\
\hline & Coefficients & Standard Error & t Stat & P-value & Lower $95 \%$ & Upper $95 \%$ \\
\hline Intercept & -10.8465 & 0.0470 & -230.8267 & 0.0000 & -10.9388 & -10.7542 \\
\hline $\operatorname{Ln}(v)$ & $-0.7466^{*}$ & 0.1976 & -3.7791 & 0.0002 & -1.1347 & -0.3585 \\
\hline
\end{tabular}
2 , group 3, respectively. Firstly, we test for the foreigner as following tables.

Table 9. Regression of volatility-buy/sell price for foreigner

Time period: January 2, 2003 - February 28, 2014 (544 observations, analyze as weekly basis) 
Table 10. Regression of volatility-buy/sell price for foreign investor in cash inflow

Time period: January 2, 2003 - February 28, 2014 (277 observations, analyze as weekly basis- cash inflow)

\begin{tabular}{|c|c|c|c|c|c|c|}
\hline \multicolumn{7}{|c|}{ Regression Statistics } \\
\hline \multicolumn{2}{|c|}{ Multiple R } & 0.0577 & & & & \\
\hline \multicolumn{2}{|c|}{ R Square } & 0.0033 & & & & \\
\hline \multicolumn{2}{|c|}{ Adjusted R Square } & -0.0003 & & & & \\
\hline \multicolumn{2}{|c|}{ Standard Error } & 1.0180 & & & & \\
\hline \multicolumn{2}{|c|}{ Observations } & 277 & & & & \\
\hline & Coefficients & Standard Error & t Stat & $\mathrm{P}$-value & Lower 95\% & Upper $95 \%$ \\
\hline Intercept & -11.0771 & 0.1030 & -107.4997 & 0.0000 & -11.2800 & -10.8743 \\
\hline $\operatorname{Ln}(v)$ & $-0.4336^{*}$ & 0.4526 & 0.9580 & 0.0034 & -0.4574 & 1.3246 \\
\hline
\end{tabular}

Table 11. Regression of volatility-buy/sell price for foreign investor in cash outflow

Time period: January 2, 2003 - February 28, 2014 (267 observations, analyze as weekly basis- cash outflow)

\begin{tabular}{|c|c|c|c|c|c|c|}
\hline \multicolumn{7}{|c|}{ Regression Statistics } \\
\hline \multicolumn{2}{|c|}{ Multiple R } & \multicolumn{5}{|l|}{0.1909} \\
\hline \multicolumn{2}{|l|}{ R Square } & \multicolumn{5}{|l|}{0.0365} \\
\hline \multicolumn{2}{|c|}{ Adjusted R Square } & \multicolumn{5}{|l|}{0.0328} \\
\hline \multicolumn{2}{|c|}{ Standard Error } & \multicolumn{5}{|l|}{1.1590} \\
\hline \multicolumn{2}{|c|}{ Observations } & \multicolumn{5}{|l|}{267} \\
\hline & Coefficients & Standard Error & t Stat & P-value & Lower $95 \%$ & Upper 95\% \\
\hline Intercept & -10.9529 & 0.1090 & -100.5078 & 0.0000 & -11.1675 & -10.7384 \\
\hline $\operatorname{Ln}(v)$ & $1.3917 *$ & 0.4395 & -3.1664 & 0.0017 & -2.2570 & -0.5263 \\
\hline
\end{tabular}

Table 9-11 are shown the impact of foreign investor to stock market, including cash inflow and outflow. It can conclude that there is a negative relationship between trading and volatility in foreign investor. However, the relation between volatility and flow depends on the direction of flow. Fund inflow is negative related to market volatility while fund outflow is positive relation.

According to our result, it agrees with several empirical researches (i.e Lensink and Morrissey (2006), Chang and Wang (2002)). Lensink and Morrissey (2006) studied the volatility of trading flow for foreign investor. They found that volatility has a negative impact on growth. In addition, Chang and Wang (2002)'s study supported this idea. They examined the daily relation between aggregate flow into U.S equity funds and market volatility. They found the impact of fund inflow and outflow on the market volatility. They found that fund inflow is negatively correlated with market volatility while fund outflow is positively correlated with market volatility. In the other word, they explained that the larger is the aggregate cash flow out of the funds, the more volatile is the market.

In addition, we test for the local and institution investors as following tables:

Table 12. Regression of volatility-buy/sell price for local investor

Time period: January 2, 2003 - February 28, 2014 (544 observations, analyze as weekly basis)

\begin{tabular}{|c|c|c|c|c|c|c|}
\hline \multicolumn{7}{|c|}{ Regression Statistics } \\
\hline \multicolumn{2}{|c|}{ Multiple R } & \multicolumn{5}{|l|}{0.1633} \\
\hline \multicolumn{2}{|l|}{ R Square } & \multicolumn{5}{|l|}{0.0267} \\
\hline \multicolumn{2}{|c|}{ Adjusted R Square } & \multicolumn{5}{|l|}{0.0249} \\
\hline \multicolumn{2}{|c|}{ Standard Error } & \multicolumn{5}{|l|}{1.0954} \\
\hline \multicolumn{2}{|c|}{ Observations } & \multicolumn{5}{|l|}{544} \\
\hline & Coefficients & Standard Error & t Stat & P-value & Lower 95\% & Upper $95 \%$ \\
\hline Intercept & -10.8503 & 0.0470 & -230.9946 & 0.0000 & -10.9426 & -10.7581 \\
\hline $\operatorname{Ln}(v)$ & -1.7101 & 0.4436 & 3.8547 & 0.1298 & 0.8386 & 2.5816 \\
\hline
\end{tabular}


Table 13. Regression of volatility-volume for institution investor

Time period: January 2, 2003 - February 28, 2014 (544 observations, analyze as weekly basis)

\begin{tabular}{|c|c|c|c|c|c|c|}
\hline \multicolumn{7}{|c|}{ Regression Statistics } \\
\hline \multicolumn{2}{|c|}{ Multiple R } & \multicolumn{5}{|l|}{0.0678} \\
\hline \multicolumn{2}{|l|}{ R Square } & \multicolumn{5}{|l|}{0.0046} \\
\hline \multicolumn{2}{|c|}{ Adjusted R Square } & \multicolumn{5}{|l|}{0.0028} \\
\hline \multicolumn{2}{|c|}{ Standard Error } & \multicolumn{5}{|l|}{1.1078} \\
\hline \multicolumn{2}{|c|}{ Observations } & \multicolumn{5}{|l|}{544} \\
\hline & Coefficients & Standard Error & t Stat & P-value & Lower $95 \%$ & Upper $95 \%$ \\
\hline Intercept & -10.8485 & 0.0475 & -228.3770 & 0.0000 & -10.9418 & -10.7552 \\
\hline $\operatorname{Ln}(v)$ & -0.3002 & 0.1898 & -1.5814 & 0.1144 & -0.6731 & 0.0727 \\
\hline
\end{tabular}

Table 12-13 are shown that there is no correlation between trading and volatility for both of local and institution investor. According to above testing, it can conclude that the impact of investor groups, including foreigner, local and institution, to stock market. Both of local and institution investors do not impact to market volatility. Foreign investor has positive relation between trading and market volatility, depending on the flow direction. Fund inflow is negatively correlated while fund outflow is positively.

\section{Conclusion}

The impact of stock market has become interesting since the stock crash of October 1987. This paper presents and proves the impact in Thai stock market, started January 2, 2003 to February 28, 2014. According to those period, the stock return has fluctuated especially in in 2007 or the started period of Sub-prime crisis, and in 2009 or during global economic crisis, started in Q3 2008 to 2009.

After examine the volatility, it has shown the high volatility during the same period of time for both of frequency volatility or standard volatility method as standard deviation, and extremely volatility or Parkinson (1980) volatility. In addition, to prevent the robustness, this paper study the correlation between those methods, this is shown as high correlation. As a result, even the different method, it still shows that same direction of volatility.

In addition, this paper examines the relation between return-volume, and between volatility-volume. There are several empirical studies that explained in this topic. After examined Thai stock market data, we found that there is a positive relation in return-volume relation and negative in volatility-volume. When volume will increase, return increases while volatility decreases.

Moreover, we study the impact of investor groups to stock return and market volatility. We separate the investor groups into three main groups that are foreign, local and institution investors. This paper differentiates the impact of fund inflow and outflow for each investor. The results show that both of local and institution investors do not impact to stock market in both of stock return and market volatility. Foreign investor has positive relation between trading-volume, and negative relation between trading-market volatility. However, depending on direction flow, fund inflow in trading-volume is positively correlated while outflow is negatively. Trading-volatility in fund inflow has negative correlated while outflow is positively.

\section{Acknowledgments}

We are deeply thank you to all Professors in Ph. D program at National Institute of Development Adminstration for their valuable advice and knowledge, which help to complete this empirical study. We would like to give a special thank you to our families for their patient, and support us toward the complement of this study. Additionally, we would like to thanks those whose names are not mentioned here but have greatly inspired and encouraged me until this study becomes complete.

\section{References}

Brooks, C. (1998, January). Predicting stock index volatility: can market volume help? Journal of Forecasting, 17(1), 59-80. http://dx.doi.org/10.1002/(SICI)1099-131X(199801)17:1<59::AID-FOR676>3.0.CO;2-H

Campbell, Y. J. (1992, June). No news is good news: An asymmetric model of changing volatility in stock returns. Journal of Fianancial $281-318$. http://dx.doi.org/10.1016/0304-405X(92)90037-X 
Chan, G. M., Firth, M., \& Oliver, M. R. (2001, August). The Dynamic Relation between Stock Returns, Trading $\begin{array}{llll}\text { Volume, and } \quad \text { Volatility. } & \text { Financial }\end{array}$ http://dx.doi.org/10.1111/j.1540-6288.2001.tb00024.x

Chan, K., \& Fung, W. M. (1998, January). Trade size, order imbalance, and the volatility-volume relation. Journal of Financial Economics, 57(1), 59-80.

Chang, C. E., \& Wang, Y. (2002, May 17). A Study of Mutual Fund Flow and Market Return Volatility. Conference Submission.

Choe, H., Kho, C. B., \& Stulz, R. M. (1999, October). Do foreign investors destabilize stock markets? The Korea experience in 1995. Journal of Financial Economics, 54(2), 227-264. http://dx.doi.org/10.1016/S0304-405X(99)00037-9

Clark, K. P. (1973, January). A subordinated Stochastic process model with finite variance for speculative prices. Econometrica, 41, 135-55. http://dx.doi.org/10.2307/1913889

Dooley, M., \& Hutchison, M. (2009, December). Transimission of the U.S. Subprime crisis to emerging markets: Evidence on the decoupling- recoupling hypothesis. Journal of International Money and Finance, 28(8), 1331-1349. http://dx.doi.org/10.1016/j.jimonfin.2009.08.004

Edwards, R. F. (1988, August). Future trading and cash market volatility: Stock index and interest rate futures. Journal of Futures Markets, 8(4), 421-439. http://dx.doi.org/10.1002/fut.3990080404

Engle, F. R., \&Victor, K. N. G. (1993, December). Measuring and Testing the Impact of News and Volatility. The Journal of Finance, 48(4), 1749-1778. http://dx.doi.org/10.1111/j.1540-6261.1993.tb05127.x

French, K. R., Schwert, G. W., \& Stambaugh. (1987, September). Expected stock returns and volatility. Journal of Financial Economics, 19(1), 3-30. http://dx.doi.org/10.1016/0304-405X(87)90026-2

Fung, H. G., \& Patterson, A. G. (1999, January). The dynamic relationship of volatility, volume and market depth in currency futures market. Journal of International Financial Markets, Institution and Money, 9(1), 33-59. http://dx.doi.org/10.1016/S1042-4431(98)00035-3

Guo, H., \& Savichas, R. (2006). Idiosyncratic Volatility, Stock Market Volatility, and Expected Stock Returns. Journal of Business \& Economic Statictics, 24(1), 43-56. http://dx.doi.org/10.1198/073500105000000180

Haugen, A. R., \& Baker, L. N. (1991, Spring). The efficient market inefficiency of capitalization- weighted stock portfolios. The Journal of Portfolio Management, 17(3), 35-40. http://dx.doi.org/10.3905/jpm.1991.409335

Hsu, C. P. (2013). The Influence of Foreign portfolio Investment on Domestic Stock Returns: Evidence from Taiwan. The International Journal of Business and Finance Research, 7(3b), 1-11.

Jaffe, J., \& Westerfield, R. (1985, June). The week-end effect in common stock returns: The international evidence. The Journal of Finance, 40(2), 433-454. http://dx.doi.org/10.1111/j.1540-6261.1985.tb04966.x

Lensink, R., \& Morrissey, O. (2006, August). Foreign Direct Investment: Flows, Volatility, and the Impact on $\begin{array}{lllll}\text { Growth. Review of International } & \text { Economics, }\end{array}$ http://dx.doi.org/10.1111/j.1467-9396.2006.00632.x

Li, J., \& Wu, C. (2006, September). Daily Return Volatility, Bid-Ask Spreads, and Information Flow: Ananlyzing the Information Content of Volume. The Journal of Business, 79(5). http://dx.doi.org/10.1086/505249

Manaster, S., \& Koehler, G. (1982, March). The Calculation of Implied Variances from the Black-Scholes Model: A Note. The Journal of Finance, 37(1). http://dx.doi.org/10.1111/j.1540-6261.1982.tb01105.x

Parknson, M. (1980). The extreme value method for estimating the variance of the rate return. Journal of Business, 53, 61-66. http://dx.doi.org/10.1086/296071

Reilly, F. K. (1979). How institutional trading reduces market volatility. Journal of Portfolio Management, 5 , 11-17. http://dx.doi.org/10.3905/jpm.1979.408682

Richards, A. (1990, March). Big Fish in Small Ponds: the trading Behaviour and Price Impact of Foreign Investors in Asian Emerging Equity Markets. Journal of Financial and Quantitative Analysis, 40(1), 1-27. http://dx.doi.org/10.1017/S0022109000001721

Schwert, G. W. (1989, May). Stock Market Volatility. Financial Analysis Journal, 46(3), $23-34$. http://dx.doi.org/10.2469/faj.v46.n3.23

Schwert, G. W. (1990). Stock Volatility and the crash of 87. The review of Financial Studies, 3(1), 77-102. 
http://dx.doi.org/10.1093/rfs/3.1.77

Takada, K. (2014, March 20). China Opens door further to foreign stock investors. Reuters.

Warther, V. (1995). Aggregate mutual fund flows and security returns. Journal of Financial Economics, 39, 209-235. http://dx.doi.org/10.1016/0304-405X(95)00827-2

Warther, V. (1998). Has the rise of mutual funds increased market instability? Brookings-Whartoon Papers on Financial Services, 239-262.

\section{Copyrights}

Copyright for this article is retained by the author(s), with first publication rights granted to the journal.

This is an open-access article distributed under the terms and conditions of the Creative Commons Attribution license (http://creativecommons.org/licenses/by/3.0/). 